\title{
Evaluation on Health Policy Implementation for Decreasing Maternal Mortality Rate through Prenatal Class Program in East Ogan Komering Ulu, South Sumatera
}

\author{
Elfina Saragih'), Hari Purwadi²), Isharyanto²) \\ ${ }^{1)}$ Masters Program in Law,Universitas Sebelas Maret \\ ${ }^{2)}$ Faculty of Law, Universitas Sebelas Maret
}

\begin{abstract}
Background: An indicator to determine public health is maternal mortality rate (MMR). Based on the Indonesian Demographic and Health Survey (IDHS) in 2012, MMR in Indonesia was still at 359 per 100,000 live births. Community participation is very supportive in efforts to reduce maternal mortality through prenatal class. This study aimed to explore the implementation of prenatal class as an effort to reduce maternal mortality.

Subjects and Method: This was a qualitative descriptive study. The study was carried out in east Ogan Komering Ulu, South Sumatera, Indonesia. Key informants consisted of 5 subjects namely Head of east Ogan Komering Ulu Health Office, Head of family health section, Head of Rawa Bening Health Center, 10 midwives, and head village. The data were collected by in-depth interview, observation, and document review.

Results: Prenatal class activities in Rawa Bening community health center have been implemented for a long time. Stakeholders worked together in accordance with their respective tasks and functions. Prenatal class activities have resulted in increased knowledge of mothers and families about pregnancy, postpartum care, newborn care, and family planning. However, pregnant women who were participated in prenatal class was still low.

Conclusions: Prenatal class program in east Ogan Komering Ulu, has been implemented according to the implementation guidelines. However, pregnant women who were participated in prenatal class is still low.
\end{abstract}

Keywords: maternal class program, maternal mortality rate, evaluation

\section{Correspondence:}

Elfina Saragih. Masters Porgram in Law, Universitas Sebelas Maret. Jl. Ir. Sutami 36A, Surakarta, Central Java, Indonesia. Email: elfinasaragih@gmail.com. Mobile: +628527066626

\section{BACKGROUND}

This study aims to analyze the implementation of KIH as an effort to reduce maternal mortality in the Ogan Komering Ulu Timur District of the Government since 1990 making strategic efforts in an effort to reduce AKI through the Safe Motherhood Initiative program, which is to ensure all women get the care needed during pregnancy and delivery, which was followed up with the Gerakan Sayang Ibu (GSI) program in 1996. Then in 2000, the Ministry of Health of the Republic of Indonesia strengthened the strategy with a safe Pregnancy National Movement (Ministry of Health, 2012). In 2012, there was an increase in MMR so the Ministry of Health of the Republic of Indonesia launched expanding maternal and neonatal survival program. The strategy made by the Government should be supported by community participation. The government and the community are responsible for ensuring that every mother has access to quality health services (UNSAID, 2014) 
Journal of Health Policy and Management (2019), 4(2): 111-116

https://doi.org/10.26911/thejhpm.2019.04.02.06

MMR is the death of pregnant women within 42 days after the end of pregnancy without considering the age and type of pregnancy as complications of labor or childbirth with related or aggravated causes of pregnancy and pregnancy management, but not because of an accident (WHO, 2012).

The maternal death in Indonesia is $80 \%$ caused by direct obstetric causes such as bleeding, sepsis, unsafe abortion, preeclampsia-eclampsia, and congestion. The remaining $20 \%$ occurs because of diseases that are aggravated by pregnancy. The cause of bleeding is still high even though it tends to decrease from $35.1 \%$ to $30.3 \%$, while the cause of maternal mortality in Indonesia is still 3 main problems (bleeding, preeclampsia-eclampsia, and infection) (Ministry of Health, 2014).

Based on the Indonesian Demographic and Health Survey (IDHS, 2012) MMR in Indonesia was still at 359 per 100,000 lives birth. High maternal mortality rate was not in line with Millennium Development Goals (MDGs) 2000-2015. MDGs contain a set of transformative goals that are agreed upon and apply to all nations without exception. MDGs goals number 3 is ensuring a healthy life and promoting prosperity for all people of all ages, by reduce maternal mortality to below 70 per 100,000 live births.

Ministry of Health (2015) reported that Indonesia has not succeeded in reducing maternal mortality. The success of the SDGs cannot be separated from the important role of the regional government, because the city and district governments: (a) are closer to their citizens; (b) have authority and funds; (c) can carry out various innovations; and (d) are the spearhead of public service providers and various government policies and programs (SDGs, 2015).
According to the data as stated in the Profile of the Privinsi Health Office of South Sumatra, there were as many as 165 cases of maternal deaths in 2017 (South Sumatra Health Office, 2017). Data from the East OKU district health office shows that there were 17 deaths in the birth of 17 cases in 2017 (Health Office, OKUT 2017). MMR in East Oku Regency in 2007 was the highest in South Sumatera, Indonesia, in 2017. MMR causes were due to circulatory system disorders (6 mothers), eclampsia (4 mothers), bleeding (1 mother), metabolic disorders ( 1 mother), and others cause ( 5 mothers). Because of the high MMR, a system is needed to accelerate the decline in MMR. Efforts to accelerate the reduction of MMR have been carried out, among others, through increasing accessibility and quality of services carried out by bringing health services closer to the community through the placement of midwives and Poskesdes in various corners of the country. While from the aspect of service quality, it is carried out through efforts to increase the ability/competence of health workers and basic health and referral facilities (PONED/ PONEK), as well as other intervention programs (Ministry of Health, 2013). To suppress MMR can not only be done by health workers, but also requires crossprogram cooperation, across sectors and participation from the community.

Article 46 Paragraph (2) Regulation of the Minister of Health Number 97 year 2014 concerning health services before pregnancy, pregnancy, childbirth, and after childbirth, implementation of contraception services, and sexual health services, stipulates that efforts to achieve optimal maternal health require participation the community includes organizing prenatal class as an effort to reduce MMR. Community participation is highly expected in reducing MMR because with the high 
participation of the community, the community will be able to help themselves in recognizing, solving problems, and the needs of the community, especially in the health sector, including pregnant women, pregnancy and childbirth at the facility. Health services such as Poskesdes, Puskesmas and midwife practice or doctor's practice. To improve maternal health, collaboration between the government, health services and the community is expected.

PMC was a shared learning tool that need to be followed by pregnant women in order to obtain knowledge and skills of mothers regarding pregnancy, childbirth, postpartum, postpartum family planning, prevention of complications, newborn care and physical activity/exercise for pregnant women with maximum number of participants 10 people, in PMC, pregnant women would study together, discuss and exchange experiences on maternal and child health thoroughly and systematically. The general objective of PMC was to increase knowledge, change attitudes and behavior of mothers to understand pregnancy, body changes and complaints during pregnancy, care for pregnancy, childbirth, postpartum care, postpartum family planning, newborn care and expected interaction between pregnant women, mothers with a husband and pregnant mother with family and with health personnels, it was also expected that the mother recognized the signs and dangers that might be experienced and can be immediately examined by a health facility (Ministry of Health RI, 2012).

Based on the study by Septerina et al. (2014), the implementation of the PMC program in Banyumas District has been carried out since 2012, but only 12 midwives from 331 midwives who implemented PMC who have been trained as facilitators for pregnant women and the implementtation of classes for pregnant women were in good category but the facilities were incomplete. This was similar with the study by Nurdiyan (2014) at Malalak and Baro Health Centers in Agam Regency. His study reported that the PMC implementation system was not in accordance with the PMC implementation guidelines. The implementation of health programs, especially PMC, required a practice based approach, given the consideration of local cultural and environmental backgrounds so that the teams involved in implementing the program can maximize their roles.

Izzah (2012) also mentioned that the implementation of the PMC in Bulukumba Regency, South Sulawesi, led to recommendations and support of the District Health Office with the aim of periodically increasing the knowledge of pregnant women and health monitoring of pregnant women.

The UK Department of Health has also made recommendations for the holding of PMC through the National Service Framework for Children, Young People and Maternity Services that allowed PMC to be held by health institutions and non-governmental organizations, NHS (National Health Services) in this case also provided support in terms of the budget in the implementation of the PMC (NCT Antenatal services, 2010).

\section{SUBJECTS AND METHOD}

This was a qualitative study with descripttive design. This study described precisely the characteristics of individuals, circumstances, symptoms or certain groups (Ishaq, 2016; Meoleong, 2005). The researcher chose the Rawa Bening Health Center because there were cases of maternal deaths in 2016 and 2017 in this health center.

The target number of pregnant women was 1219 mothers in 2016 and there 
were 2 cases of maternal deaths and in 2017 there were 3 cases of maternal deaths caused by circulatory system disorders and hypertension in pregnancy. The data source was the party interviewed/informant research purposively. The PMC study was conducted at the Rawa Bening Health Center in East Buay Madang Subdistrict, a working area that included 33 Villages and 123 hamlets. In this study, the informants consisted of the heads of the Health Center, Coordinating Midwives and Village Midwives who were 42 and taken 10 midwives as the study sample.

\section{RESULTS}

From the data, interviews and observations, a general description of PMC implementtation in East OKU Regency was obtained. In the implementation of the PMC, the health office was very supportive by providing training to the health center coordinator midwives and program midwives. Costs were obtained from the Regional Expenditure Budget (APBD), while the PMC Implementation was by the Facilitator using Special Allocation Funds (DAK) and Health Operational Assistance (Permenkes No. 82/2015). The coordinating midwife as trained facilitator then trains midwives in the health center working area as PMC facilitators in the villages where they were assigned. The Health Office and Health Center evaluated the implementation of the PMC program by receiving reports of PMC activities delivered by village midwives every month.

Reports submitted in stages at the village midwife conveyed to the Health Center, then the Healthc Center was reported to the family health section of the East OKU health office. In East OKU Regency, PMC has been implemented since 2009 but there were still difficulties faced to gather pregnant women. The facilities were still minimal so that the implementation of PMC was still not optimal and has obstacles. The program has been carried out in cross-sector collaboration but has not supported the success of PMC. The PMC program has been carried out in accordance with the PMC Facilitator Guidelines according to the technical guidelines made by the Ministry of Health (Ministry of Health, 2012) but the number of pregnant women was very low. Based on data on the class of pregnant women in 2017, there were 28 classes and 254 were attended by mothers, and there was no data that showed the presence of husbands or families of PMC participants.

Context: East OKU Regency was the first rank in South Sumatra Province in terms of the high MMR of 16 cases in 2017. It took the role of the community to convey the interests of the community and demand their rights to be better services and to convey views to service providers and the government responsibly and quality.

Input: East OKU District through the Health Service has provided support for PMC revitalization, with training activities aimed at Health Center coordinating Midwives, to be able to convey to village midwives about PMC material, all village midwives have been given PMC facilitator handbooks and PMC implementation handbooks. Propagated by using APBD funds. The implementation of the PMC program and the cost of MCC facilitator official travel were taken from the BOK funds.

Process: After the socialization of the PMC program was held to all relevant stakeholders, a schedule was arranged and the PMC implementation activities were determined. This activity was based on the expectation of a decrease in the number of maternal mortality rates. Therefore, it was necessary to tabulate pregnancy data in 
order to determine the material for delivering PMC activities to the right target. Output: Increased awareness of pregnant women participating in PMC activities by midwives at Rawa Bening Health Center, Buay Madang Tinur Sub-District, East OKU Regency. The long-term impact that can be generated from this activity was that the community can improve the idea of the importance of checking pregnancy and childbirth to the health facilities that have been provided. The expected follow-up was that the community, especially pregnant women, wanted to take part in the PMC program. Activities that have been running, were expected not only to be a program, but also sustainable and can provide great impact and benefits and enthusiasm in maintaining health both during pregnancy, childbirth and postpartum. The involvement of various stakeholders and the creation of a commitment to continue to support the implementation of this program was important, because the problem of many cases of maternal deaths was not only the government's responsibility to resolve them.

\section{DISCUSSION}

The high maternal and infant mortality rates were still the main focus in a country. There have been many efforts to improve maternal health such as placing village midwives, building village health posts, health center. community participation efforts to reduce MMR, included complication and prevention prevention planning program, organizing the PMC, partnership between midwives and traditional birth attendants, and maternity waiting home utilization (PermenkesNo 97 /2014)

From the results of the study, it can be concluded that all health centers in the East OKU district of Oku Timur district have implemented the PMC program.
However, in reality, the support from husbands or families was very poor, it can be seen from the data, it showed that they did not find any presence of the family when pregnant women attended the PMC meeting.

The prenatal class program as an effort to reduce maternal mortality has been carried out in East OKU Regency. However, in the practice of implementtation, it was not optimal because: (i) has not fully paid attention and implemented the implementation guidelines; (ii) limited facilities and infrastructures; (iii) understanding of pregnant women and stakeholders; and (iv) lack of husband or family support in PMC membership.

\section{REFERENCES}

Departemen kesehatan RI (2010). Rencana strategis nasional making pregnancy safer (MPS) di Indonesia 2001 2010. Jakarta.

Dinas Kesehatan Sumatera Selatan (2017). Profil Dinas Kesehatan Privinsi Sumatera Selatan.

Dinas Kesehatan OKU Timur (2017). Profil Dinas Kesehatan Kabupaten Ogan Komering Ulu Timur.

Haveret (2015). Experiences engaging community health workers to provide maternal and newborn health services.

Ishaq H (2017). Metode Penelitian Hukum, Alfa Beta, Bandung.

Izzah A (2014). Memantau kehamilan melalui kelas ibu hamil di Kabupaten Bulukumba. 2011. http://igi.fisipol.ugm.ac.id.

INFID (2015). Panduan SDGs Untuk Pemerintah Daerah (Kota dan Kabupaten) dan Pemangku Kepentingan Daerah, International NGO Forum on Indonesian Development (INFID), Jakarta

(2013). Rencana aksi percepatan penurunan angka kematian ibu di 
Journal of Health Policy and Management (2019), 4(2): 111-116

https://doi.org/10.26911/thejhpm.2019.04.02.06

Indonesia. http://www.gizikia.depkes.go.id.

(2014). Pusat Data dan Informasi (info datin) Jakarta.

(2015). Kesehatan Dalam Kerangka Sustainable Development Goals (SDGs), Rapat Koordinasi Kementerian Kesehatan RI Dirjen Bina Gizi KIA Selaku Ketua Sekretariat Pembangunan Kesehatan Pasca-2015, Jakarta.

Miller MA, Stoeckel PR (2011). 1st edn. Sudbury, Massachusetts, US: Jones and Bartlett. Client education theory and practice.

Moleong J (2005). Metodologi penelitian kualitatif, Bandung: Remaja Rosdakarya.

Nurdiyan A, Desmiwarti, Rizanda Machmud (2014). Analisis Sistem Pelaksanaan Kelas Ibu Hamildi Puskesmas Malalak dan Biaro Kabupaten Agam.

NCT Antenatal services (2010) Policy, practice and evidence. London: National Childbirth Trust;

Kemenkes (2012). Badan Kependudukan dan Keluarga Berencana Nasional Badan Pusat Statistik. Jakarta.

Permenkes Nomor 97 Tahun 2014 Tentang Pelayanan Kesehatan Masa Sebelum Hamil, Masa Hamil, Persalinan, Dan Masa Sesudah Melahirkan, Penyelenggaraan Pelayanan Kontrasepsi, serta Pelayanan Kesehatan Seksual.

Permenkes RI Nomor 82 Tahun 2015 tentang petunjuk teknis penggunaan dana bantuan operasional kesehatan.

Septerina PW, Hastuti P, Fitria Z (2014). Evaluasi proses pelaksanaan kelas ibu hamil di Kabupaten Banyumas, 80 Bidan Prada: Jurnal Ilmiah Kebidan- an. 5(2). http://ejournal.poltekkessmg.ac.id/ojs/index.php/jurkeb/articl e/viewFile/95/61.

USAID (2014).EMAS (Expanding Maternal and Neonatal Survival).Panduan Operasional: Sistem Jejaring Rujukan Kegawat daruratan Ibu dan Bayi Baru Lahir Puskesmas dan Rumah Sakit.

Peraturan Menteri Kesehatan Republik Indonesia Nomor 59/MENKES/PER/XII/2012 Tentang Petunjuk Teknis Bantuan Operasional Kesehatan.

Peraturan Menteri Kesehatan Republik Indonesia Nomor 97 Tahun 2014 tentang pelayanan kesehatan masa sebelum hamil, masa hamil, persalinan, dan masa sesudah melahirkan, penyelenggaraan pelayanan kontrasepsi, serta pelayanan kesehatan seksual.

Peraturan Menteri Kesehatan Republik Indonesia Nomor 75 Tahun 2014 tentang pusat kesehatan masyarakat.

Peraturan Menteri Kesehatan Republik Indonesia Nomor 82 Tahun 2015 tentang petunjuk teknis penggunaan dana alokasi khusus bidang kesehatan serata sarana dan pra sarana penunjang subbidang sarpras kesehatan.

Peraturan Menteri Kesehatan Republik Indonesia Nomor 43 Tahun 2016 tentang Stendar Pelayanan Minimal Bidang Kesehatan;

Peraturan Menteri Kesehatan Republik Indonesia Nomor 47 Tahun 2016 tentang fasilitas pelayanan kesehatan.

Peraturan Menteri Kesehatan Republik Indonesia Nomor 26 Tahun 2017 tentang izin dan penyelenggaraan praktik bidan. 